\title{
Peripheral Limb Gangrene in Neonates
}

\author{
Vignesh Subramanu ${ }^{1}$, Renu Suthar ${ }^{2}$, Rakesh Pilania ${ }^{3}$, Lokesh Saini ${ }^{4}$, Venkataseshan Sundaram ${ }^{5}$, Suresh K Angurana ${ }^{6}$
}

\begin{abstract}
Peripheral limb gangrene in neonates presenting soon after birth is rare and exact etiology could not be ascertained in majority. In order to make an important contribution to the limited literature on this topic, we report rare and unique presentation of peripheral limb gangrene in two neonates soon after birth (on day 1 of life) involving lower limbs. The etiology could not be ascertained, despite extensive workup. Both cases were managed with supportive care and low-molecular-weight heparin and developed auto-amputation of toes.

Keywords: Auto-amputation, Low-molecular-weight heparin, Neonates, Peripheral gangrene.

Journal of Postgraduate Medicine, Education and Research (2021): 10.5005/jp-journals-10028-1402
\end{abstract}

\section{INTRODUCTION}

Peripheral limb gangrene in neonates is rare entity, and various predisposing factors implicated include prematurity, dehydration, sepsis, umbilical artery cannulation, hypercoagulable state, pregnancy-induced hypertension, and maternal diabetes. ${ }^{1-4}$ The exact etiology of peripheral limb ischemia and gangrene in neonates presenting at or soon after birth is unknown in majority of reported cases. ${ }^{1,5}$ Possible causes postulated are distal arterial occlusion by emboli from placenta, ductus arteriosus, or umbilical arteries; birth trauma, polycythemia, arterial spasm, external compression of limbs between fetal skull and maternal pelvis; and constriction band or constriction by umbilical cord leading to microcirculatory insufficiency. ${ }^{1,2,5}$ The simultaneous presence of number of these causative factors may be required to develop peripheral gangrene, and this may explain the rarity of this condition. ${ }^{5}$ There are only few case reports of peripheral limb gangrene in neonates presenting soon after birth. ${ }^{1-3,5-10}$ We report two neonates who presented with peripheral limb gangrene soon after birth, etiology of which was not obvious despite extensive workup and both developed auto-amputation of toes.

\section{Case Descriptions}

\section{Case 1}

A term, $2700 \mathrm{~g}$ female baby born by vaginal delivery with normal perinatal transition presented with complaints of bluish-black discoloration of left foot noted soon after birth. Examination revealed tachypnea, palpable femoral and dorsalis pedis arteries, gangrene involving all the toes and lateral border of left foot (Fig. 1A), and normal systemic examination. Investigations are shown in Table 1. She was started on intravenous antibiotics, subcutaneous low-molecular-weight heparin (LMWH, enoxaparin) $2 \mathrm{mg} / \mathrm{kg} / \mathrm{day}$, and daily wound dressing. There was no further progression of the lesions, and baby was discharged after 14 days. At follow-up after 1 month, there was auto-amputation of all toes of left foot (Fig. 1B). The LMWH was stopped, and she was planned to undergo protein $C$ and $S$ and antithrombin III estimation in follow-up.

\section{Case 2}

A term, $3500 \mathrm{~g}$ male baby delivered by vaginal delivery with normal perinatal transition, presented on day 1 with a small erythematous
${ }^{1-6}$ Department of Pediatrics, Postgraduate Institute of Medical
Education and Research, Chandigarh, India

Corresponding Author: Suresh K Angurana, Department of Pediatrics, Postgraduate Institute of Medical Education and Research, Chandigarh, India, Phone: +91 2147483647, e-mail: sureshangurana@gmail.com

How to cite this article: Subramanu V, Suthar R, Pilania R, et al. Peripheral Limb Gangrene in Neonates. J Postgrad Med Edu Res 2021;55(4):177-179.

Source of support: Nil

Conflict of interest: None

lesion over toes of both lower limb that progressed over time into a bullous lesion and later turned blackish and progressed up to knees. Examination revealed gangrene involving all toes and lateral aspect of ankle of left foot (Fig. 2A), right foot, and leg up to knee joint (medially) (Fig. 2B) as well as left thigh and left scrotum. Bilateral femoral, popliteal, and dorsalis pedis arteries were palpable, and systemic examination was normal. Investigations are mentioned in Table 1. He was started on broad-spectrum antibiotics and subcutaneous LMWH. There was no progression of the lesions and subsequently was discharged after 11 days. In follow-up after
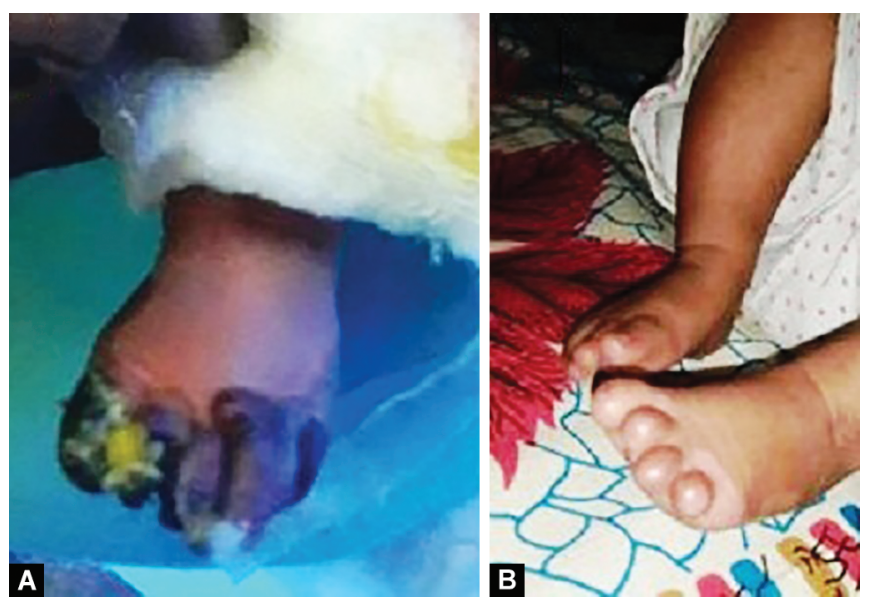

Figs $1 \mathrm{~A}$ and B: (A) Gangrene involving all toes and lateral aspect of left foot; (B) Auto-amputation of all toes of left foot in follow-up

(-) The Author(s). 2021 Open Access This article is distributed under the terms of the Creative Commons Attribution 4.0 International License (https://creativecommons. org/licenses/by-nc/4.0/), which permits unrestricted use, distribution, and non-commercial reproduction in any medium, provided you give appropriate credit to the original author(s) and the source, provide a link to the Creative Commons license, and indicate if changes were made. The Creative Commons Public Domain Dedication waiver (http://creativecommons.org/publicdomain/zero/1.0/) applies to the data made available in this article, unless otherwise stated. 
Table 1: Investigation details in two neonates with peripheral gangrene

\begin{tabular}{|c|c|c|}
\hline Investigations & Case 1 & Case 2 \\
\hline Hemoglobin (g\%) & 21 & 13 \\
\hline $\begin{array}{l}\text { Total leukocyte count } \\
\text { (per } \mathrm{mm}^{3} \text { ) }\end{array}$ & 13,000 & 34,700 \\
\hline Platelet count (per mm³) & 300,000 & 390,000 \\
\hline Serum sodium (mEq/L) & 132 & 139 \\
\hline Serum potassium (mEq/L) & 5.8 & 5.3 \\
\hline Urea (mg\%) & 54 & 18 \\
\hline Creatinine (mg\%) & 0.2 & 0.4 \\
\hline Prothrombin time (seconds) & 16 & 12 \\
\hline Prothrombin index (\%) & 88 & 100 \\
\hline $\begin{array}{l}\text { International normalized } \\
\text { ratio }\end{array}$ & 1.1 & 1.2 \\
\hline $\begin{array}{l}\text { Activated partial } \\
\text { thromboplastin time } \\
\text { (seconds) }\end{array}$ & 47 & 39 \\
\hline $\begin{array}{l}\text { Fibrinogen (mg/dL) } \\
\text { (Normal: } 150-400 \mathrm{mg} / \mathrm{dL} \text { ) }\end{array}$ & 167 & \\
\hline $\begin{array}{l}\text { D-dimer (ng/mL) (Normal: } \\
<500 \mathrm{ng} / \mathrm{mL})\end{array}$ & 477 & 3577 \\
\hline $\begin{array}{l}\text { Procalcitonin }(\mathrm{ng} / \mathrm{mL}) \\
\text { (Normal: }<0.15 \mathrm{ng} / \mathrm{mL})\end{array}$ & 0.2 & \\
\hline Blood culture & Sterile & Sterile \\
\hline USG Doppler & $\begin{array}{l}\text { Normal blood flow } \\
\text { in left femoro- } \\
\text { popliteal vessels }\end{array}$ & $\begin{array}{l}\text { Normal blood } \\
\text { flow in bilateral } \\
\text { femoro-popliteal } \\
\text { vessels }\end{array}$ \\
\hline $\begin{array}{l}\text { Antinuclear antibodies } \\
\text { (ANA) }\end{array}$ & Negative & Negative \\
\hline $\begin{array}{l}\text { Anti-cardiolipin (ACL) } \\
\text { antibodies }\end{array}$ & Negative & Negative \\
\hline $\begin{array}{l}\text { Anti- } \beta 2 \text { glycoprotein ( } \beta 2 \mathrm{GP} \text { ) } \\
\text { antibodies }\end{array}$ & Negative & Negative \\
\hline Factor V Leiden mutation & Negative & Negative \\
\hline $\begin{array}{l}\text { Mother's ANA, LA, ACA, } \\
\text { and anti- } \beta 2 \mathrm{GP} \text { antibodies }\end{array}$ & Negative & Negative \\
\hline Protein C & Normal & Normal \\
\hline Protein S & Normal & Normal \\
\hline Antithrombin III & Normal & Normal \\
\hline
\end{tabular}

2 months, there was auto-amputation of all toes of left foot and (Fig. 2C) scar mark over right foot and leg medially (Fig. 2D). The LMWH was given for 3 months.

\section{Discussion}

Peripheral limb gangrene in neonates is extremely rare., ${ }^{1,5}$ Basic pathology for gangrene involving extremities is diminished perfusion. We postulated that the possible causes of peripheral gangrene in index cases could be arterial occlusion by emboli from placenta, ductus arteriosus, or umbilical arteries; arterial spasm; or external compression of limbs during birth based on two facts, ${ }^{1,2,5}$ leading to microcirculatory insufficiency. First, index cases had absence of any maternal risk factors, prematurity, perinatal adverse event, sepsis, polycythemia, dehydration, pro-coagulant state, and cardiac disease. Second, the gangrene developed soon after birth (pointing toward an etiology related to ante- or intrapartum events).

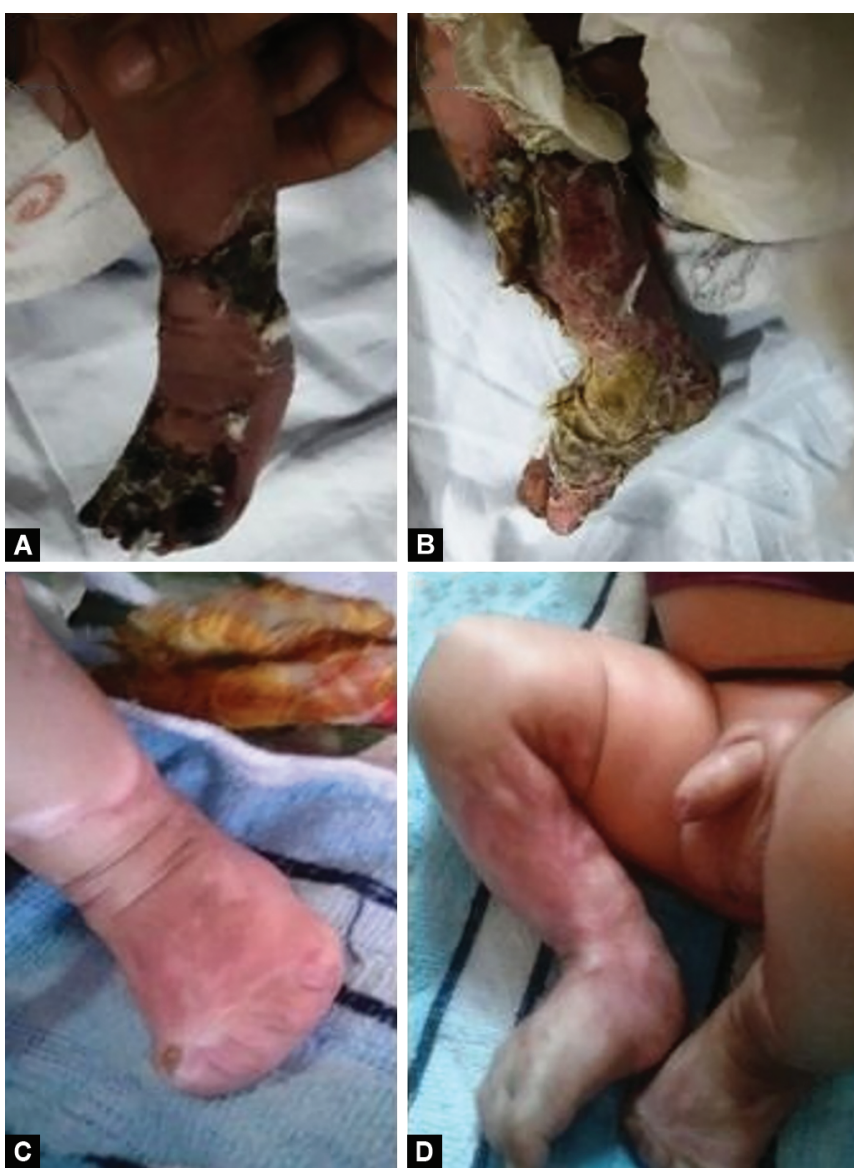

Figs 2A to D: (A) Gangrene involving all toes and dorsum of left foot and lateral aspect of left ankle joint; (B) Skin necrosis and sloughing involving dorsum of right foot and medial aspect of leg extending up to medial aspect of knee joint (after 1 week of admission). There was gangrene at same site at the time of admission; (C) Auto-amputation of all toes on left side; (D) Scar mark involving dorsum of right foot and medial aspect of leg extending up to medial aspect of knee joint

Review of literature also suggests that in majority of neonates with peripheral gangrene, the etiology could not be ascertained. ${ }^{1,5}$ Turnpenny et al. ${ }^{1}$ published a review involving 56 neonates (reported till 1992) who presented with peripheral ischemia and gangrene at or soon after birth. Authors could not find any etiology in majority. Kothari et al. ${ }^{9}$ reported 4 neonates with bilateral lower limb gangrene who required amputation. Two neonates had undergone exchange transfusion, and in two no etiology could be identified. Nagai et al. ${ }^{10}$ reported two neonates with intrauterine gangrene of bilateral lower limb complicated by prematurity and twin-to-twin transfusion syndrome requiring below-knee amputation. Neonates in index report presented soon after birth with peripheral gangrene without any identifiable cause and had auto-amputation of toes. Ahluwalia et al. ${ }^{11}$ from our center reported prothrombotic profile of 11 children (age range of 1 month to 17 years) with peripheral gangrene and noted protein $S$ deficiency and transient positivity for lupus anticoagulant in only one patient each. The authors indicated that in children with peripheral gangrene, the deficiency of protein C, protein S, antithrombin, anticardiolipin antibodies, lupus anticoagulant, and factor $V$ Leiden positivity is uncommon as causative factors.

The management of neonatal peripheral limb gangrene is conservative with antibiotics and local wound care to prevent 
secondary infection; heparin to decrease progression of thrombosis, if present; and early surgical intervention in the presence of severe or progressive ischemic changes. Care should be taken to avoid amputation prematurely till definitive demarcation line between healthy and gangrenous area develops. Amputation should be designed to preserve growth plate and to ensure adequate stump for prosthetic fitting in future. Often there is spontaneous progression to sloughing and auto-amputation ${ }^{6}$ as in index cases.

The limitation of index report is lack of definitive etiology for the development of peripheral limb gangrene in these neonates. This is similar to the findings reported by other authors, where the etiology could not be ascertained in majority of neonates and children with peripheral gangrene. ${ }^{1,5,8,9,11}$

\section{Conclusion}

Peripheral limb ischemia and gangrene presenting at or soon after birth is a rare condition. The etiology could to be ascertained in majority of the neonates. Management include supportive care and LMWH. Auto-amputation occurs in majority of the cases, and meticulous supportive treatment could decrease the loss of function of affected limb.

\section{References}

1. Turnpenny PD, Stahl $S$, Bowers $D$, et al. Peripheral ischaemia and gangrene presenting at birth. Eur J Pediatr 1992;151(8):550-554. DOI: 10.1007/BF01957717.
2. Bhettay $E$, Jacobs ME. Peripheral gangrene in the newborn. A case description, and a discussion of possible mechanisms of origin. Clin Pediatr (Phila) 1977;16(6):573-576. DOI: 10.1177/000992287701600617.

3. Dogra S, Agrawal SK, Jindal R, et al. Peripheral gangrene in a breast fed neonate-is hypernatremic dehydration the cause? Indian J Pediatr 2011;78(12):1543-1545. DOI: 10.1007/s12098-011-0418-9.

4. Chalmers EA. Neonatal thrombosis. J Clin Pathol 2000;53(6):419-423. DOI: 10.1136/jcp.53.6.419.

5. Glaun BP, Weinberg EG, Malan AF. Peripheral gangrene in a newborn. Arch Dis Child 1971;46(245):105-107. DOI: 10.1136/adc. 46.245.105.

6. Letts $\mathrm{M}, \mathrm{Blastorah} \mathrm{B}$, al-Azzam S. Neonatal gangrene of the extremities. J Pediatr Orthop 1997;17(3):397-401. DOI: 10.1097/01241398199705000-00023.

7. Singh J, Rattan KN, Gathwala G, et al. Idiopathic unilateral lower limb gangrene in a neonate. Indian J Dermatol 2011;56(6):747-748. DOI: 10.4103/0019-5154.91845.

8. Onalo R, Ogala WN, Lawal YZ, et al. Congenital gangrene of the extremities in a newborn. Niger J Clin Pract 2011;14(2):245-248. DOI: 10.4103/1119-3077.84031.

9. Kothari PR, Gupta A, Kulkarni B. Neonatal lower extremity gangrene. Indian Pediatr 2005;42(11):1156-1158.

10. Nagai MK, Littleton AG, Gabos PG. Intrauterine gangrene of the lower extremity in the newborn: a report of two cases. J Pediatr Orthop 2007;27(5):499-503. DOI: 10.1097/01.bpb.0000279024. $88751.7 \mathrm{~d}$.

11. Ahluwalia J, Naseem S, Singh S, et al. Prothrombotic profile in children with peripheral gangrene: a single center experience. Clin Appl Thromb Hemost 2011;17(5):497-501. DOI: 10.1177/ 1076029610376627. 